\title{
Conformation ability test of human, rabbit and bovine plasminogens and their specific interaction with streptokinase
}

\author{
Vitaly N. Nikandrov, Galina V. Vorobyova, Galina S. Yankovskaya and \\ Natalie V. Demidchik \\ Laboratory of Biochemistry, Byelorussian Research Institute of Epidemiology and Microbiology, Nogin \\ strasse 3, Minsk 22050, Byelorussia
}

(Received 20 May 1991; revised 20 February 1992)

\begin{abstract}
Human, rabbit and bovine plasminogens, having different sensitivity to streptokinase-activating action, differ, according to spectrophotometric titration, tryptophan fuorescence and circular dichroism spectroscopy, in the state of tyrosine and tryptophan residues, and in secondary and tertiary structures. Human plasminogen-streptokinase equimolar complex formation (according to gel chromatography) is accompanied by a differential ultraviolet spectrum. Difference spectroscopy is a convenient and adequate means of studying the formation of the said complexes. Streptokinase-human plasminogen complex formation is not hindered by partial substitution of water (20\%) with ethanol or dimethylsulphoxide or by addition of $0.001 \mathrm{M}$ sodium dodecylsulphate. The complex is not formed in $6 \mathrm{M}$ urea, in solution, at $\mathrm{pH}<2.0$ or $\sim 12.0-13.0$, or with bovine plasminogen. Circular dichroism and tryptophan fluorescence spectral pattern changes during streptokinase-plasminogen complex formation enable us to conclude that streptokinase secondary and tertiary structures undergo certain rearrangements in the framework of the complex, while tryptophan-containing sites of the molecule are not drastically changed. The data obtained enable us to presuppose formation of streptokinase-rabbit plasminogen complexes which differ from human plasminogen complexes with streptokinase.
\end{abstract}

Keywords: Streptokinase-plasminogen interactions; equimolar protein complex; spatial structure; spectroscopy

\section{Introduction}

Streptokinase (SK), an extracellular protein of haemolytic streptococci, is one of the most efficient activators of plasminogen $(\mathrm{Pg})$. An important feature of the SK function is its particularly high species specificity: human, canine and rabbit plasminogens (Pgs) are well activated in the presence of SK in contrast to extremely weak activation of bovine $\mathrm{Pg}^{1,2}$. It is supposed that one of the main reasons lies in different zymogen structure but the level of this difference is still unclear. Besides, according to the predominant hypothesis, $\mathrm{Pg}$ is activated, on the addition of SK, by an equimolar SK-Pg complex ${ }^{3}$. It is presumed that the plasmin(ogen) molecule in this complex undergoes conformational changes and these very changes cause high and unusual substrate specificity of the plasmin(ogen ) moiety of this complex. However, conformational abilities of the complex require further study.

The present study is aimed at examination of secondary and tertiary structures, tyrosine and tryptophan residue states in rabbit, human and bovine Pg molecules, and conformation abilities of these zymogens during SK activation.

\section{Experimental}

Human Pg samples were purified from a blood fraction enriched with $\beta$-globulins by affinity chromatography on lysine-Sepharose ${ }^{4}$. Rabbit and bovine Pgs were purified from blood plasma by affinity chromatography on lysine-polymer-silochrome ${ }^{5}$. Specific activity of $\mathrm{Pg}$ samples was analysed by the caseinolytic method ${ }^{6}$ after activation of human and rabbit Pgs by SK, and bovine Pg by urokinase, yielding values of 20-22 caseinolytic units $\mathrm{mg}^{-1}$ protein.

Streptokinase was isolated from the drug 'Celyase' (Byelorussia) by column chromatography with cibacron blue $\mathrm{F} 36 \mathrm{~A}-$ Sepharose $6 \mathrm{~B}^{7}$ to remove inert proteins. Specific activity of the received SK samples, according to the fibrin clot lysis method ${ }^{8}$, was $100000 \mathrm{IU} \mathrm{mg}^{-1}$ protein.

Protein concentration in purified Pg and SK samples was determined spectrophotometrically according to absorbance of aqueous solutions at $280 \mathrm{~nm} ; A_{1 \mathrm{~cm}}^{1}$ for SK was 8.8 (Ref. 9), and values for human, rabbit and bovine Pgs were 17.0, 18.1 and 15.3 , respectively ${ }^{10,11}$.

Homogeneity of the received purified protein samples was demonstrated by electrophoresis in $12.5 \%$ poly- 
acrylamide gel in the presence of sodium dodecyl sulphate ${ }^{12}$.

For the study of $\mathrm{SK}-\mathrm{Pg}$ interaction, the proteins were dissolved in $0.05 \mathrm{M}$ Tris $-\mathrm{HCl}$ buffer, $\mathrm{pH} 8.0$, containing $0.02 \mathrm{M} \mathrm{L}$-lysine $\mathrm{e}^{13}$. The final concentration of every protein in the complex was $5 \times 10^{-6} \mathrm{M}$.

Spectrophotometric titration of Pgs was carried out in $0.1 \mathrm{M} \mathrm{NaCl}$ solution on a spectrophotometer model 26 (USSR) in standard cuvettes.

Tryptophan fluorescence spectra were recorded on a Fica-55 spectrofluorometer with an excitation wavelength $\lambda=296 \mathrm{~nm}$. Quenching of fluorescence was measured on addition (immediately before measurement) of aliquots (5-10 $\mu \mathrm{l})$ of $3 \mathrm{M} \mathrm{CsCl}, \mathrm{NaNO}_{3}$ or acrylamide solutions to $2 \mathrm{ml}$ of $\mathrm{Pg}$ solution $\left(1.6-2.1 \times 10^{-6} \mathrm{M}\right)$. Quenching data were analysed according to the SternVolmer equation with correction for reabsorption ${ }^{14}$. The quantum yield of fluorescence was determined with relation to tryptophan solution yield, which was taken as 0.2 (Ref. 14).

Circular dichroism spectra were recorded on a Jasco-20 spectropolarimeter in the wavelength intervals 205$240 \mathrm{~nm}$ (protein concentration, $0.4 \mathrm{mg} \mathrm{ml}^{-1}$; cell pathlength, $0.02 \mathrm{~cm}$ ) and $250-350 \mathrm{~nm}$ (protein concentration, $1.0 \mathrm{mg} \mathrm{ml}^{-1}$; cell pathlength, $1.0 \mathrm{~cm}$ ). Data were recorded with apparatus sensitivity of $0.002-0.005^{\circ} \mathrm{cm}^{-1}$ and a scanning rate of $0.4 \mathrm{~nm} \mathrm{~s}^{-1}$. The apparatus was calibrated with D-10-camphorsulphonic acid and Dpantolactone according to instructions ${ }^{15}$. Molar ellipticity was determined, taking the mean residue weight of SK and Pg as 133.6 and 119 , respectively, according to data on amino acid composition of these proteins ${ }^{16-18}$. The quota of amino acid residues contained in secondary structure elements was estimated using BESM-6 and SM-14 computers (USSR) on protein-derived basic spectra of five elements of secondary structure ${ }^{19}$. When $\mathrm{Pg}$ and SK were mixed, the amino acid residue weight (126) was taken as the mean residue weight of both proteins.

All studies were repeated at least four times. The following preparations were used: 'Celyase' (Byelorussia) or 'Streptase' (Behringwerke AG, Germany), Urokinase (JCR), L-lysine, acrylamide and polyacrylamide gel reagents (Reanal, Hungary), D-pantolactone, D-10camphorsulphonic acid, cibacron blue (Serva, Germany), 6B Sepharose and $\mathrm{BrCN}$-Sepharose (Pharmacia, Sweden); human fibrinogen and thrombin and Hammerstein casein were made in the USSR along with $\varepsilon$-aminocaproic acid, organic solvents and inorganic salts (analytical grade), which were further purified.

\section{Results}

Conformational specificity of human, rabbit and bovine plasminogens

During spectrophotometric titration, tyrosine residues in the human Pg molecule are ionized in two stages (Figure 1). First, six tyrosyls are ionized ( $\mathrm{pK} 10.2)$, the rest are ionized with further $\mathrm{pH}$ enhancement ( $\mathrm{p} K 11.0)$, possibly after conformational transition. The process is reversible. In rabbit and bovine Pg molecules there is one-stage ionization of tyrosine residues with $\mathrm{p} K$ 11.2. The total number of tyrosine residues in human, rabbit and bovine Pgs is 24,33 and 35, respectively, according to spectrophotometric titration with $\Delta E_{295}=2400$

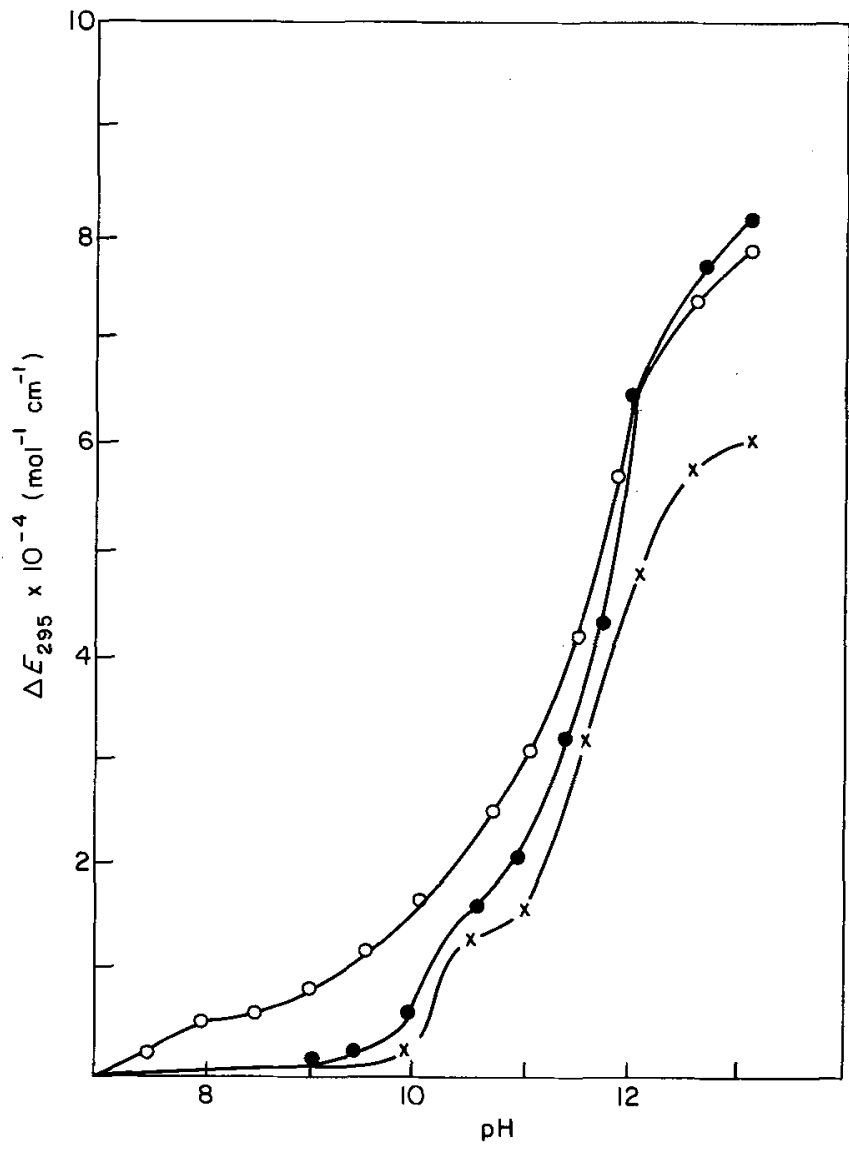

Figure 1 Spectrophotometric titration of tyrosine residues of human $(x)$, rabbit $(O)$ and bovine $(O)$ plasminogens. Human plasminogen concentration is $6 \times 10^{-6} \mathrm{M}$, rabbit and bovine plasminogen concentration is $3 \times 10^{-6} \mathrm{M}$; the solvent is $0.1 \mathrm{M}$ $\mathrm{NaCl}$ solution; for $\mathrm{pH}$ variation $0.1 \mathrm{M}$ and $0.01 \mathrm{M}$ solutions of $\mathrm{NaOH}$ and $\mathrm{HCl}$ are used

Table 1 Values of the Sterner-Volmer constant $\left(\mathrm{mol}^{-1}\right)$

\begin{tabular}{lcl}
\hline & \multicolumn{2}{c}{ Stern-Volmer constant } \\
\cline { 2 - 3 } Plasminogen & $\mathrm{NO}_{3}^{-}$ & Acrylamide \\
\hline Human & 7.5 & 2.5 \\
Rabbit & 10.4 & 6.0 \\
Bovine & 6.5 & 3.2 \\
\hline
\end{tabular}

$\mathrm{mol}^{-1} \mathrm{~cm}^{-1}$ for one residue ${ }^{20}$. This conforms with amino acid analysis data ${ }^{17,18}$.

It is well known that the number of tryptophan residues in the above Pgs is 20,19 and 22 , respectively ${ }^{17,18}$. At the same time, tryptophan fluorescence quantum yields $(q)$ of these zymogens equal $0.06,0.11$ and 0.18 (in $0.6 \mathrm{M}$ phosphate buffer, $\mathrm{pH} 7.4$, containing $0.2 \mathrm{M} \mathrm{NaCl}$ ). The positions of the maxima $\left(\lambda_{\max }\right)$ and half-widths $(\Delta \lambda)$ of the tryptophan fluorescence spectra for human $\mathrm{Pg}$ are $336 \mathrm{~nm}$ and $58 \mathrm{~nm}$, for rabbit $\mathrm{Pg} 336 \mathrm{~nm}$ and $59 \mathrm{~nm}$ and bovine $\mathrm{Pg} 340 \mathrm{~nm}$ and $60 \mathrm{~nm}$, respectively. The fluorescence of these Pgs is not affected by $\mathrm{Cs}^{+}$ions (the degree of quenching does not exceed $8 \%$ ), but is considerably quenched by $\mathrm{NO}_{3}^{-}$and by acrylamide. Values for the Sterner-Volmer constant are given in Table 1.

According to the circular dichroism spectra in the far ultraviolet (u.v.) region, the zymogens differ in secondary 
Wovelength $(\mathrm{nm})$

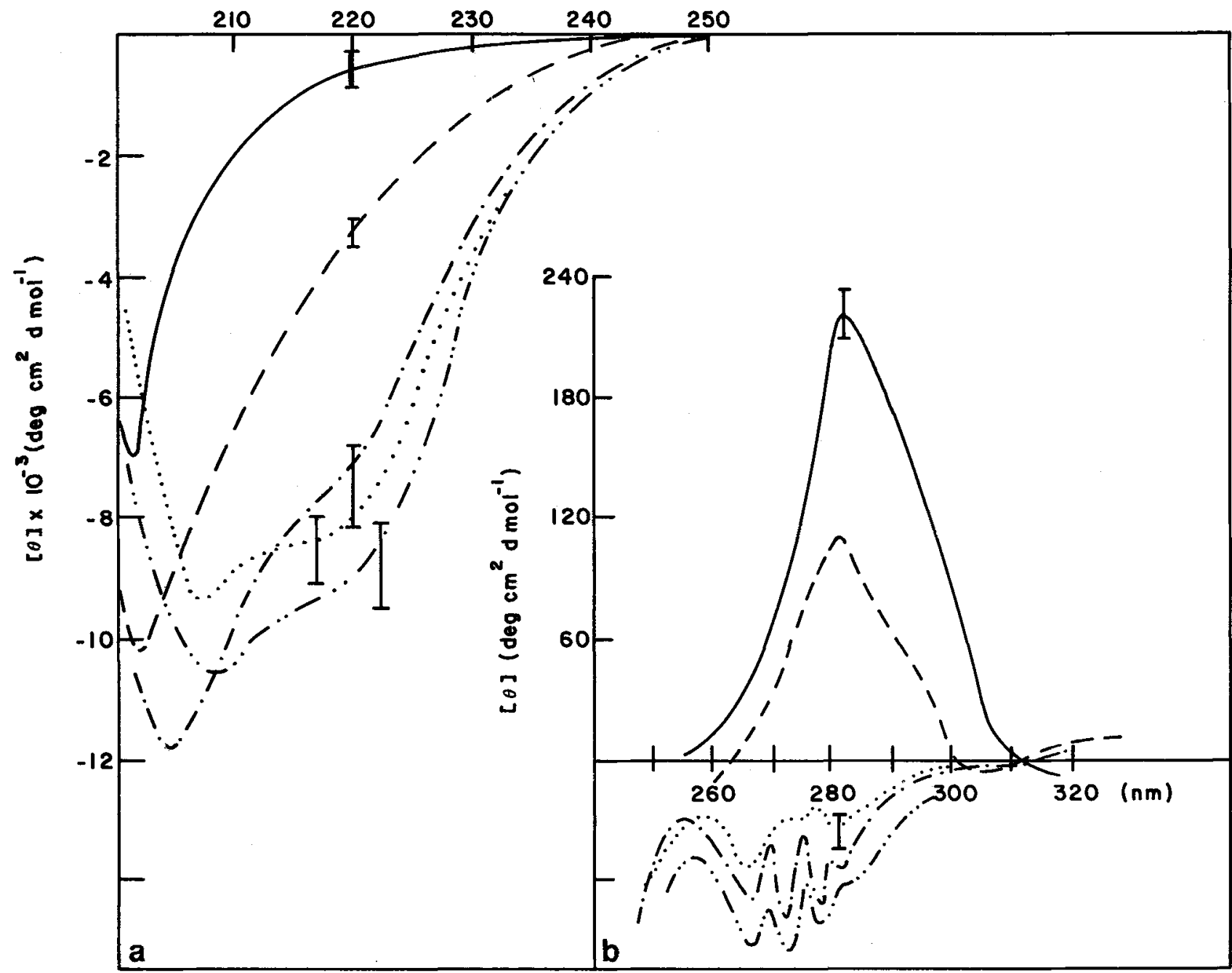

Figure 2 Circular dichroism spectra of human $(--)$, rabbit $(\ldots \ldots \ldots)$ and bovine $(-. .-\cdots-)$ plasminogens, streptokinase $(-\cdot \cdots-)$ and equimolar mixture of streptokinase and human plasminogen (---) in far (a) and near (b) ultraviolet regions.

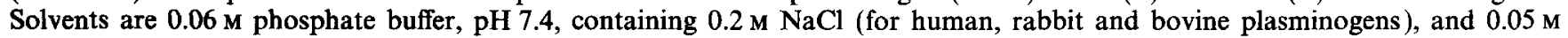

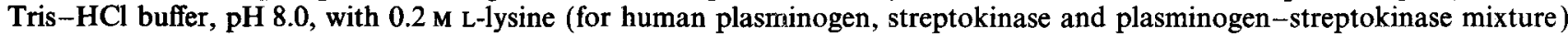

structures (Figure 2). Analysis of the protein-derived basic spectra shows that the 'random coil' is predominant in human $\mathrm{Pg}$, while $\alpha$-helices and anti-parallel $\beta$ structures are predominant in rabbit and bovine Pgs (Table 2). The asymmetry of the chromophore environment also differs between those Pgs (Figure 2). The near u.v.-region circular dichroism spectrum of human Pg has an intensive and unstructured band in the $270-300 \mathrm{~nm}$ region with a maximum at $281-282 \mathrm{~nm}$ (possibly due to the predominance of optical transitions of tyrosine residues). The circular dichroism spectra of rabbit and bovine Pgs have characteristic weak negative bands with peaks at $267-269,272-274$ and $278-282 \mathrm{~nm}$ (this is characteristic for ${ }^{1} \mathrm{~L}_{\mathrm{b}}, \mathrm{O}-\mathrm{O}$ transitions of tyrosine residues, and ${ }^{1} \mathrm{~L}_{\mathrm{a}}$ transitions of tryptophan residues ${ }^{21,22}$.

Conformational specificity of plasminogens during their mixing with streptokinase

A stable complex is formed when SK and human Pg are mixed in conditions that exclude proteolytic action of plasmin on the SK molecule. This complex was discovered by means of gel chromatography on a G-200

Table 2 Secondary structure of human, rabbit and bovine plasminogen molecules $(0.06 \mathrm{M}$ phosphate buffer, $\mathrm{pH} 7.4)$

\begin{tabular}{|c|c|c|c|c|c|}
\hline \multirow[b]{3}{*}{ Plasminogen } & \multicolumn{5}{|c|}{ Relative content $(\%)$ of secondary structural elements } \\
\hline & \multirow[b]{2}{*}{$\alpha$-helices } & \multicolumn{2}{|c|}{$\beta$-structures } & \multirow[b]{2}{*}{$\beta$-turns } & \multirow{2}{*}{$\begin{array}{l}\text { Random } \\
\text { coil }\end{array}$} \\
\hline & & Antiparallel & Parallel & & \\
\hline Human & $6.3 \pm 0.3$ & $7.9 \pm 1.3$ & $5.0 \pm 0.5$ & $19.5 \pm 2.0$ & $61.3 \pm 5.0$ \\
\hline Rabbit & $34.0 \pm 1.5$ & $21.4 \pm 3.0$ & $2.5 \pm 0.3$ & $22.0 \pm 2.5$ & $20.1 \pm 1.5$ \\
\hline Bovine & $31.4 \pm 2.8$ & $13.0 \pm 1.3$ & $2.8 \pm 0.3$ & $18.0 \pm 2.0$ & $34.8 \pm 2.0$ \\
\hline
\end{tabular}






Figure 3 Difference spectra of human plasminogen-streptokinase mixtures with molar ratio $0.3: 1(-\cdot-\cdot-\cdot)$ and $1: 1$ (--- ); difference spectra of equimolar human plasminogenstreptokinase mixture in the presence of $6 \mathrm{M}$ urea or in solution at $\mathrm{pH} 1.8(\cdots \cdots)$, and under partial substitution of water with ethanol $(---)$ ), dimethylsulphoxide $(-)$ or in presence of $0.001 \mathrm{M}$ sodium dodecyl sulphate (-..-...--). In all cases

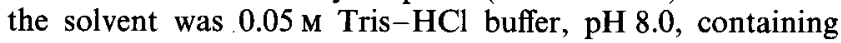
$0.2 \mathrm{M} \mathrm{L}-$ lysine, and $0.05 \mathrm{M} \mathrm{KCl}$ solution (acidified by $\mathrm{HCl}$ ) was used for obtaining $\mathrm{pH}$ 1.8. During the titration, protein concentration was $0.51 \mathrm{mg} \mathrm{ml}^{-1}$ and $4.0 \mathrm{mg} \mathrm{ml}^{-1}$ for streptokinase and human plasminogen, respectively

Sephadex column (figure not shown) as previously described $^{13}$. The difference spectroscopy analysis shows that a differential spectrum appears with a $\mathrm{Pg}$ :SK molar ratio of $0.3: 1$, and reaches a maximum at a ratio of $1: 1$ (Figure 3). This conforms with data on the protein ratio in the stable complex ${ }^{13,23}$. In the differential spectrum there are intensive peaks at $284 \mathrm{~nm}$ and $288-289 \mathrm{~nm}$ (due to tyrosine residues) and a weak band at $293 \mathrm{~nm}$ (due to tryptophanyls). Bovine $\mathrm{Pg}$ does not form complexes with SK $^{24}$ and under similar conditions no differential spectrum could be found when SK is mixed with bovine $\mathrm{Pg}$.

Neither in the presence of $6 \mathrm{M}$ urea, nor at $\mathrm{pH} \mathrm{1.8,} \mathrm{does}$ the mixing of SK and human $\mathrm{Pg}$ lead to the formation of differential spectra. This is in agreement with data on the absence of an $\mathrm{SK}-\mathrm{Pg}$ complex at $\mathrm{pH} \leqslant 3.0$, or with the addition of urea ${ }^{13}$. The above data prove that the differential spectrum is an inherent property of the SK-Pg complex. Spectroscopy is a more convenient means to study $\mathrm{Pg}-\mathrm{SK}$ complex formation than ultracentrifugation, gel chromatography or electrophoresis, especially when kinetic studies are needed.

The differential spectrum does not appear when SK and $\mathrm{Pg}$ are mixed at $\mathrm{pH} 11.6$. However, the spectrum is not affected by partial $(20 \%)$ substitution of water by ethanol or dimethylsulphoxide, nor by addition of sodium dodecyl sulphate (Figure 3).

The mixing of $\mathrm{SK}$ and human $\mathrm{Pg}$ at a ratio of $1: 1$ leads to an alteration of the circular dichroism spectra and, in particular, to changes in molar ellipticity, $[\theta]_{220}$ and $[\theta]_{280}$ (Figure 2, Table 3); $[\theta]_{220}$ of the complex deviates from the theoretical value by $14 \%$, and $[\theta]_{280}$ by $34 \%$. When $\mathrm{SK}$ and bovine $\mathrm{Pg}$ are mixed, molar ellipticity changes are in accordance with theoretical values (Table 3). The changes are only evidence of contribution to the spectra by two proteins. For the first $20 \mathrm{~min}$, after SK and rabbit $\mathrm{Pg}$ are mixed, no deviation of molar ellipticity from theoretical values occurs. However, after $90 \mathrm{~min}[\theta]_{220}$ and $[\theta]_{280}$ differ from theoretical values by 11 and $21 \%$, respectively, in contrast to bovine $\mathrm{Pg}$.

When $\mathrm{SK}$ and human $\mathrm{Pg}$ are mixed in buffer-salt solution, according to equimolar ratio, $\lambda_{\max }$ shifts, the half-width of spectrum changes, and tryptophan fluorescence is partially quenched (Table 4$)$. Values of $\lambda_{\max }$ and $\Delta \lambda$ of the protein mixture are intermediate between values for the separate proteins. The substitution of water by ethanol $(20 \%)$ does not introduce any changes, while the addition of dimethylsulphoxide causes a hypsochromic shift of $\lambda_{\max }$ of the mixture up to $\lambda_{\max }$ of $\mathrm{Pg}$. The $\Delta \lambda$ value of the $\mathrm{SK}-\mathrm{Pg}$ complex corresponds in this case to that of $\mathrm{Pg}$, but no quenching of fluorescence is observed. In the presence of sodium dodecyl sulphate the $\lambda_{\text {max }}$ position of the $\mathrm{SK}-\mathrm{Pg}$ complex corresponds to that of $\mathrm{Pg}$ alone, the $\Delta \lambda$ value is between those of SK and $\mathrm{Pg}$ and fluorescence is weakly quenched. In $6 \mathrm{M}$ urea, where stable complexes are not formed, only $\lambda_{\max }$ of the mixture shifts to a value intermediate between those of SK and Pg.

\section{Discussion}

The data obtained prove marked differences in conformation of human, rabbit and bovine Pg molecules. The difference lies in the state of the tyrosine residues. The nitration of these residues in human Pg hampers the formation of a $\mathrm{Pg}-\mathrm{SK}$ complex ${ }^{25}$. Those residues are supposed to be involved in the formation of the complex. However, all the above Pgs have surface tyrosine

Table 3 Molar ellipticity [ $\theta]\left(\mathrm{deg} \mathrm{cm}^{2} \mathrm{dmol}^{-1}\right)$ values of streptokinase, plasminogens and streptokinase-plasminogen equimolar mixtures (0.05 M Tris-HCl buffer, $\mathrm{pH} 8.0$, containing $0.2 \mathrm{M}$ L-lysine)

\begin{tabular}{llccc}
\hline & \multicolumn{2}{c}{$-[\theta]_{220} \times 10^{-3}$} & & {$[\theta]_{280}$} \\
\cline { 2 - 4 } Samples in study & Experimental & Theoretical & Experimental & Theoretical \\
\hline Human plasminogen & 0.5 & & +202 & \\
Streptokinase & 8.2 & & -48 & +116 \\
Mixture & 3.8 & 4.4 & -40 & -57 \\
Bovine plasminogen & 8.1 & & -65 & \\
Streptokinase & 78 & 8.0 & -51 & \\
Mixture & 8.1 & & -69 & \\
Rabbit plasminogen & 9.7 & & -60 & \\
Streptokinase & 7.8 & 8.7 & -79 & -65 \\
Mixture & 7.7 & & & \\
\hline
\end{tabular}


Table 4 Effect of partial substitution of water with organic solvents ( $20 \%$ vol), addition of sodium dodecyl sulphate and urea on tryptophan fluorescence spectra parameters of streptokinase, human plasminogen and their equimolar mixtures $(0.05 \mathrm{M}$ Tris- $\mathrm{HCl}$ buffer, $\mathrm{pH} 8.0$, containing $0.2 \mathrm{M} \mathrm{L}$-lysine; streptokinase and plasminogen concentrations are $5 \times 10^{-6}$ and $2.5 \times 10^{-6} \mathrm{M}$ respectively, concentrations of streptokinase and plasminogen in equimolar mixtures are $2.5 \times 10^{-6} \mathrm{M}$

\begin{tabular}{|c|c|c|c|c|c|}
\hline \multirow[b]{2}{*}{ Experimental conditions } & \multirow[b]{2}{*}{ Protein samples } & \multirow{2}{*}{$\begin{array}{l}\lambda_{\max } \\
(\mathrm{nm})\end{array}$} & \multirow{2}{*}{$\begin{array}{l}\Delta \lambda \\
(\mathrm{nm})\end{array}$} & \multicolumn{2}{|c|}{$I_{\text {relative }}$} \\
\hline & & & & Experimental & Theoretical \\
\hline $\begin{array}{l}\text { Control } \\
(0.05 \mathrm{M} \text { Tris- } \mathrm{HCl} \text { buffer }+0.2 \mathrm{M} \\
\text { L-lysine })\end{array}$ & $\begin{array}{l}\text { Plasminogen } \\
\text { Streptokinase } \\
\text { Mixture }\end{array}$ & $\begin{array}{l}336 \\
341 \\
339\end{array}$ & $\begin{array}{l}59 \\
64 \\
62\end{array}$ & $\begin{array}{l}1.56 \\
1.00 \\
1.76\end{array}$ & 2.06 \\
\hline Addition of ethanol & $\begin{array}{l}\text { Plasminogen } \\
\text { Streptokinase } \\
\text { Mixture }\end{array}$ & $\begin{array}{l}335 \\
340 \\
337\end{array}$ & $\begin{array}{l}60 \\
68 \\
66\end{array}$ & $\begin{array}{l}1.93 \\
1.23 \\
2.17\end{array}$ & 2.54 \\
\hline Addition of dimethylsulphoxide & $\begin{array}{l}\text { Plasminogen } \\
\text { Streptokinase } \\
\text { Mixture }\end{array}$ & $\begin{array}{l}337 \\
340 \\
336\end{array}$ & $\begin{array}{l}64 \\
70 \\
64\end{array}$ & $\begin{array}{l}1.41 \\
1.20 \\
1.93\end{array}$ & 2.01 \\
\hline Addition of sodium dodecyl sulphate & $\begin{array}{l}\text { Plasminogen } \\
\text { Streptokinase } \\
\text { Mixture }\end{array}$ & $\begin{array}{l}340 \\
337 \\
340\end{array}$ & $\begin{array}{l}64 \\
68 \\
66\end{array}$ & $\begin{array}{l}1.30 \\
0.94 \\
1.25\end{array}$ & 1.77 \\
\hline Addition of urea $(6 \mathrm{M})$ & $\begin{array}{l}\text { Plasminogen } \\
\text { Streptokinase } \\
\text { Mixture }\end{array}$ & $\begin{array}{l}338 ; 360 \\
343 ; 360 \\
340 ; 360\end{array}$ & $\begin{array}{l}70 \\
70 \\
70\end{array}$ & $\begin{array}{l}1.28 \\
0.90 \\
1.53\end{array}$ & 1.73 \\
\hline
\end{tabular}

residues, which are well ionized. Consequently, the absence of complex of SK and rabbit or bovine Pg could hardly be explained by the above reasons only. The studies of tryptophan fluorescence show a peculiar state of tryptophan-containing sites of zymogen molecules. It seems that, in human $\mathbf{P g}$, the tryptophanyls are located near fluorescence-quenching groups of protein. The circular dichroism spectra demonstrate most clearly the peculiarities of conformation of the three zymogens. Human Pg is characterized by a lesser number of ordered elements of secondary structure and by a different organization of tertiary structure. Previously, tryptophan fluorescence studies have shown that the structure of human Pg is more flexible than that of bovine Pg during heating and addition of guanidine hydrochloride ${ }^{26}$. It is possible to assume that the $\mathrm{SK}-\mathrm{Pg}$ contact ensures structural 'tuning' of the zymogen. This phenomenon could lead to formation of a stable SK-human Pg complex.

Difference spectroscopy demonstrates that the SK-Pg complex is preserved in the presence of ethanol, dimethylsulphoxide or sodium dodecyl sulphate. It is possible that intramolecular hydrophobic interactions do not play a significant role in the formation of this complex. There are no stable SK-Pg complexes in $6 \mathrm{M}$ urea, or at $\mathrm{pH}$ values of 1.8 , or 11.6 , while SK preserves its activity under these conditions ${ }^{9}$. This supports the assumption that formation of the above complexes is not necessary for SK to manifest its activating function ${ }^{27}$. Circular dichroism spectroscopy shows that in the SK-Pg complex the SK secondary structure seems to be disordered and the tertiary structure seems to be reorganized (similarly in alkaline medium ${ }^{9}$ ). This assumption is corroborated by the higher number of elements in the native SK secondary structure, compared with $\mathrm{Pg}^{9}$, and by the demonstrated reorganization of the SK structure. The studies of rabbit Pg disprove the well established view ${ }^{27}$ that no stable SK-rabbit Pg complexes exist and confirm specific interaction of these proteins. This phenomenon requires further investigation.
The studies of tryptophan fluorescence spectra show that formation of SK-Pg complexes does not dramatically change the state of tryptophan-containing sites. The alteration of parameters of the tryptophan fluorescence spectrum cannot by itself explain the process of SK-Pg interaction. It is possible that tryptophan residues are not directly involved in the interaction.

Thus, the evident conformational differences between human, rabbit and bovine Pgs cannot by themselves completely explain specificity of SK action. The published data and experiments confirm that the formation of a SK - Pg complex is followed by changes in SK conformation. However, these cannot account for the unusual substrate specificity of the $\mathrm{Pg}$ part of the complex (see Introduction). The new hypothesis on the activating function of SK, which we described previously ${ }^{28}$ and which advances a superoxide-dependent mechanism, appears to be necessary.

\section{References}

1 Ablondi, F. B. and Hagan, J. J. Proc. Soc. Exp. Biol. Med. $1958,99,769$

2 Wulf, R. J. and Mertz, E. T. Can. J. Biochem. 1969, 47, 927

3 Castellino, F. J. Trans. Int. Biochem. 1979, 1, 1

4 Brockway, W. J. and Castellino, F. J. J. Biol. Chem. 1971, 246, 4641

5 Demidchik, N. V. in 'Streptokinase in the Regulation of Hemostatic and Antihemostatic Systems' (Eds N. E. Savchenko et al.), Byeloruss. Res. Inst. Epidemiol. Microbiol. Minsk, 1985, p 109

6 Taylor, F. B. and Tomar, R. H. Methods Enzymol. 1970, 19,807

7 Scopes, R. K. 'Protein Purification. Principles and Practice'. Springer-Verlag, New York, 1982

8 Nikandrov, V. N., Pyzhova, N.S. and Votyakov, V. J. Voprosy Med. Khimii 1987, 33, 84

9 Nikandrov, V. N., Vorobyova, G. V., Yankovskaya, G. S., Pyzhova N. S. and Mikuts, N. V. Proc. Acad. Sci. Byeloruss. SSR. Ser. Biol. Sci. 1986, 6, 47

10 Wohl, R. C., Arzadon, L., Summaria, L. and Robbins, K. C. J. Biol. Chem. 1977, 252, 1141

11 Summaria, L., Arzadon, L., Bernabe, P. and Robbins, K. C. J. Biol. Chem. 1973, 248, 6522

12 Weber, K. and Osborn, M. J. Biol. Chem. 1969, 244, 4406 
Conformation ability test of human rabbit and bovine plasminogens: $V . N$. Nikandrov et al.

13 De Renzo, E. C., Boggiano, E., Barg, W. and Buck, F. F. J. Biol. Chem. 1967, 242, 2428

14 Burstein, E. A. 'Intrinsic Fluorescence of Protein (Nature and Application)', All-Union Inst. Sci.-Techn. Information Publ., Moscow, 1977

15 Tuzimura, K., Konno, T., Meguro, H. et al. Anal. Biochem. $1977,81,167$

16 Morgan, F. and Henschen, A. Biochim. Biophys. Acta 1969, 181, 93

17 Wohl, R. C., Sinio, L., Summaria, L. and Robbins, K. C. Biochim. Biophys. Acta 1983, 745, 20

18 Collen, D. Thromb. Haemost. 1980, 43, 77

19 Bolotina, I. A. et al. Int. J. Quant. Chem. 1979, 16, 819

20 Fujioka, H. and Imahori, K. J. Biochem. 1963, 53, 244

21 Kahn, P. C. Methods Enzymol. 1979, 61, 339
22 Auer, H. E. and Schlitz, T. Int. J. Peptide Prot. Res. 1984, 24, 569

23 De Renzo, E. C., Barg, W., Boggiano, E., Englert, M. E. and Davies, M. C. Biochem. Biophys. Res. Commun. 1963, 12, 105

24 Buck, F. F., Hummel, B. C. W. and De Renzo, E. C. J. Biol Chem. 1968, 243, 3648

25 Nedkov, P. and Ninh, K. Z. Proc. Acad. Sci. Bulgar. Chem. $1978,11,173$

26 Nikandrov, V. N. and Demidchik, N. V. in 'Molecular mechanisms of metabolic process regulation. Book of abstracts of Byelorussian, Lithuanian, Latvian and Estonian biochemists' (Eds I. D. Volotovsky et al.), Byeloruss. Biochem. Soc., Minsk, 1987, pp 183-184

27 Schick, L. A. and Castellino, F. J. Biochemistry 1973, 12, 4315

28 Nikandrov, V. N. Int. J. Biochem. 1992, 24, 47 